\title{
THE ANALYSIS TOTAL PHENOLIC EXTRACT NONI FRUIT (Morinda citrifolia L.) AS INHIBITING ACTIVITY OF BACTERIA
}

\author{
${ }^{1 *}$ Hasri, ${ }^{1 *}$ Maryono, ${ }^{2 *}$ Trianita sari \\ $1,2 *$ Department of Chemistry, Faculty of Mathematics and Natural Science, State University of \\ Makassar \\ hasriu@unm.ac.id
}

\begin{tabular}{l}
\hline Artikel Info \\
Diterima \\
tanggal \\
20.01 .2018 \\
Disetujui \\
publikasi \\
tanggal \\
30.04 .2018 \\
Kata kunci :, \\
Antibacterial, \\
noni fruit, total \\
phenolic.
\end{tabular}

\begin{abstract}
ABSTRAK
Buah mengkudu (Morinda citrifolia, L.) telah digunakan sebagai obat herbal yang berfungsi sebagai analgesik, anti rdang dan antibakteri. Hal ini menunjukkan bahwa buah mengkudu mengandung senyawa aktif flavonoid, fenolik dan terpenoid Penelitian ini bertujuan menganalisis fenolik total buah mengkudu (Morinda Citrifolia, L) menggunakan pengekstrak etanol dan etil asetat serta uji hambat aktivitas terhadap bakteri Escherichia coli. Hasil analisis diperoleh fenolik total ekstrak etanol sebesar $171,91 \mathrm{mg} / \mathrm{L}$ dan ekstrak etil asetat $23,27 \mathrm{mg} / \mathrm{L}$. Ekstrak etanol dan etil asetat dapat menghambat aktivitas bakteri Escherichia coli. Ekstrak etanol memiliki konsentrasi hambat minimum (KHM) sebesar 6,5\% namun tidak demikian dengan ekstrak etil asetat, sehingga disimpulkan bahwa ekstrak etanol berpotensi menghambat aktivitas bakteri Escherichia coli lebih baik dibanding ekstrak etil asetat.
\end{abstract}

\section{ABSTRACT}

Noni fruit (Morinda citrifolia, $L$.) has been used as an herbal that serves as an analgesic, antiinflammatory and antibacterial. This research indicate that the noni fruit contain active compounds flavonoid, phenolic and terpenoid. The aimed of this study was to determine the total phenolic content of ethanol and ethyl acetate extracts of noni (Morinda citrifolia, $L$ ) and the antibacterial activity against Escherichia coli. The analysis result obtained the total phenolic extract of ethanol 171,91 $\mathrm{mg} / \mathrm{L}$ and extract of ethyl acetate 23,27 $\mathrm{mg} / \mathrm{L}$. Ethanol and ethyl acetate extracts can inhibit the activity of Escherichia coli bacteria. Ethanol extract has a minimum inhibitory concentration (KHM) of $6.5 \%$ but not with ethyl acetate extract, so it is concluded that ethanol extract potentially inhibit the activity of Escherichia coli bacteria better than ethyl acetate extract.

\section{PENDAHULUAN}

Tanaman umumnya bermanfaat sebagai obat, salah satunya adalah tanaman mengkudu. Tanaman mengkudu tergolong tumbuhan serba guna. Semua bagian tanaman mengkudu mengandung zat-zat kimia dan nutrisi yang berguna bagi kesehatan. Tanaman mengkudu telah digunakan secara tradisional untuk berbagai jenis penyakit. Masyarakat Indonesia menggunakan buah mengkudu sebagai obat herbal, diantaranya untuk mengobati penyakit kanker dengan meminum air rebusan daun mengkudu segar. Hal tersebut didukung oleh berbagai penelitian tentang kandungan senyawa aktif pada bagian tanaman mengkudu 
berupa senyawa golongan flavonoid, asam fenolik, terpenoid, dan lain-lain dalam berbagai ekstrak tanaman mengkudu.

Senyawa fenolik buah mengkudumempunyai aktivitas yang beragam seperti aktivitas antibakteri, antiseptik, dan antioksidan serta memiliki banyak manfaat untuk kesehatan. Senyawa fenolik juga berperan sebagai antioksidan berbagai penyakit degenaratif seperti kanker, menghambat pertumbuhan dan metabolisme mikroba. (Saraswaty, dkk., 2013; Hermawan dan Laksono,2013). Mikroba mudah tumbuh ditempat yang memiliki nutrisi tinggi seperti bahan makanan, karena merupakan media tumbuh bakteri yang baik, dan mudah mengalami kerusakan (Harsojo, dkk.,2005).Buah mengkudu (Morinda citrifolia, L.) menjadi salah satu bahan alam yang mengandung senyawa aktif seperti flavonoid, fenolik, terpenoid, sehingga berpotensi sebagai antibakteri, namun sejauh ini belum diketahui kandungan fenolik sebagai antibakteri menggunakan ekstrak etil asetat dan etanol.

Berdasarkan uraian di atas, dipandang perlu dilakukan penelitian tentang analisis total fenolik ekstrak etanol dan etil asetat buah mengkudu dan daya hambatnya terhadap bakteri E.coli.

\section{METODE}

\section{Alat dan Bahan}

Alat digunakan dalam penelitian ini adalah evaporator, pisau, neraca analitik, penyaring buchner, jarum ose, peralatan gelas, inkubator, autoklaf, hot plate, stopwatch, instrumen UVTampak. Bahan yang digunakan adalah buah mengkudu matang, larutan metanol, larutan etanol 96\%, bakteri Escherichia coli, kertas saring, kertas wathman, aquades, medium nutrient agar (NA) sintetik, asam galat, $\mathrm{Na}_{2} \mathrm{CO}_{3}$, reagen folin ciocalteu, kapas, paper disc, pereaksi wagner, $\mathrm{FeCl} 5 \%$, asam asetat anhidrat, asam sulfat

\section{Prosedur Penelitian}

\section{Ekstrak Buah Mengkudu (Morinda citrifolia, L.).}

Buah mengkudu matang dicuci bersih, dipotong tipis dan dikeringkan. Sebanyak 500 gram sampel di maserasi menggunakan masing-masing pelarut etanol dan etil asetat selama $2 \times 24$ jam. Ekstrak diuapkan sampai diperoleh ekstrak kental buah mengkudu (Morinda citrifolia, L.). Analisis senyawa aktif secara kualitatif dilakukan dengan cara menempatkan lima tetes larutan ekstrak dan dua tetes pereaksi. Untuk menguji positif atau negatif. 


\section{Analisis Fenolik Total}

Dilakukan dengan metoda Folin-Ciocalteu (Yuarini., dkk, 2011). Konsentrasi ditentukan menggunakan Kurva Kalibrasi Asam Galat dengan Reagen Folin-Ciocalteau. Masing masing sampel diukur serapannya pada panjang gelombang $764 \mathrm{~nm}$.

\section{Uji hambatan aktivitas bakteri}

Dilakukan dengan metode difusi agar menggunakan masing-masing ekstrak buah mengkudu. Selanjutnya bakteri Escherichia coli digoreskan secara merata ke medium. Hasil inkubasi menunjukkan zona bening disekitar paper disc, menandakan adanya efek penghambatan larutan uji terhadap bakteri uji

\section{HASIL DAN PEMBAHASAN}

Mengkudu merupakan tanaman yang berkhasiat karena mempunyai beberapa kandungan senyawa yang penting bagi kesehatan tubuh. Mengkudu banyak digunakan sebagai obat diabetes, kanker, tumor, radang ginjal, liver, tekanan darah tinggi, radang empedu, sakit perut, masuk angin dan antibakteri. Komponen yang bersifat antibakteri dalam buah mengkudu antara lain adalah glikosida, scopoletin), acubin, L. Asperuloside, dan flavonoid (Winarti, 2005). Tanpa aktivitas antibakteri ekstrak etanol buah mengkudu terhadap bakteri menyebabkan pembusukan pada daging segar. Ketika aktivitas ekstrak dapat menghambat atau membunuh bakteri, kemungkinan dapat diaplikasikan sebagai bahan pengawet makanan. Ekstrak metanol senyawa antibakteri buah mengkudu bersifat polar, dan aktivitas antibakteri yang dihasilkan lebih besar dari pada pelarut etil asetat dan n- heksan (Jayaraman dan muthu, 2008). Namun penggunaan ekstrak metanol untuk aplikasi bahan pengawet makanan dapat beresiko karena metanol bersifat toksik, sehingga dalam penelitian ini digunakan pelarut etanol dan etil asetat.

Uji fitokimia meliputi uji alkaloid, flavonoid, fenol, steroid dan terpenoid. Ekstrak mengkudu dengan pelarut etanol positif mengandung senyawa alkaloid, flavanoid, fenol, dan terpenoid. Namun ekstrak etil asetat positif mengandung senyawa alkaloid, flavanoid, fenol dan steroid. Keberadaan alkaloid terdeteksi dalam ekstrak etanol dan etil asetat. Alkaloid bersifat basa sehingga sangat mudah larut dalam pelarut yang polar. Senyawa terpenoid dan senyawa steroid memiliki sifat semipolar. Namun pada penelitian ini senyawa terpenoid hanya tertarik pada pelarut etanol sedangkan senyawa steroid hanya tertarik pada pelarut etil asetat. 
Hasil penelitian menunjukkan bahwa tidak semua senyawa kimia terdeteksi dalam ke dua ekstrak yang di peroleh. Hasil lengkapnya dapat dilihat pada Tabel 1.

Tabel 1. Analisis senyawa aktif hasil ekstrak etanol dan etil asetat buah mengkudu

\begin{tabular}{ll}
\hline \multirow{2}{*}{ Senyawa kimia } & \multicolumn{2}{c}{ Hasil Ekstrak } \\
\cline { 2 - 2 } & Etil asetat Etanol \\
\hline
\end{tabular}

$\begin{array}{lcc}\text { Alkaloid } & + & + \\ \text { Terpenoid } & - & + \\ \text { Steroid } & + & - \\ \text { Flavanoid } & + & + \\ \text { Fenol } & + & +\end{array}$

$+:($ Mengandung senyawa $) ;-($ Tidak mengandung senyawa $)$

Pada analisis fenol, ketika sampel ditambah dengan akuades dan reagen FolinCiocalteau dihasilkan sampel berwarna kuning, selanjutnya ditambahkan dengan $\mathrm{Na}_{2} \mathrm{CO}_{3} 20 \%$ warna yang dihasilkan berubah menjadi berwarna biru, kemudian nilai absorbansi diperoleh menggunakan spektrofotometer UV pada panjang gelombang $764 \mathrm{~nm}$. Hasil analisis dapat dilihat pada Tabel 2.

Tabel 2. Pengukuran sampel ekstrak etanol dan etil asetat (kandungan total fenolik) Ekstrak etanol dan etil asetat buah mengkudu

\begin{tabular}{ccc}
\hline Sampel & $\begin{array}{c}\text { Konsentrsi } \\
(\mathrm{mg} / \mathrm{L})\end{array}$ & $\begin{array}{c}\text { Konsentrasi x Fp } \\
(\mathrm{mg} / \mathrm{L})\end{array}$ \\
\hline $\begin{array}{c}\text { Ekstrak } \\
\text { Etanol }\end{array}$ & 17,191 & 171,91 \\
$\begin{array}{c}\text { Ekstrak } \\
\text { Etil asetat }\end{array}$ & 2,327 & 23,27 \\
\hline
\end{tabular}

Hasil analisis menunjukkan bahwa kandungan fenolik total dari ekstrak etanol buah mengkudu lebih tinggi di bandingkan ekstrak etil asetat, masing masing sebesar 171,91 mg/L dan 23,27 mg/L. Hal ini dapat terjadi karena senyawa golongan fenol bersifat polar atau semi polar (Hayati dkk, 2010). Flavonoid yang merupakan golongan terbesar dari senyawa golongan 
fenol bersifat polar sehingga akan banyak terdapat pada ekstrak etanol. Sementara, pada ekstrak etil asetat dimungkinkan banyak terdapat senyawa yang bersifat kurang polar.

Hasil uji pendahuluan ekstrak buah mengkudu menunjukkan bahwa ekstrak etanol dan ekstrak etil asetat menunjukkan hasil yang positif untuk ke dua jenis bakteri. Hal ini dapat dilihat dari daerah hambat yang dibentuk, yaitu berupa zona bening yang tidak ditumbuhi oleh mikrobia uji. Hambatan yang terlihat sebagai daerah yang tidak adanya pertumbuhan bakteri pada sekitar paper disk hasil uji menunjukkan bahwa ekstrak eatnol dan etil asetat memiliki aktivitas antimikrobia yang diujikan (Yunus, 2009). Hasil yang di peroleh dapat dilihat pada Gambar 1.
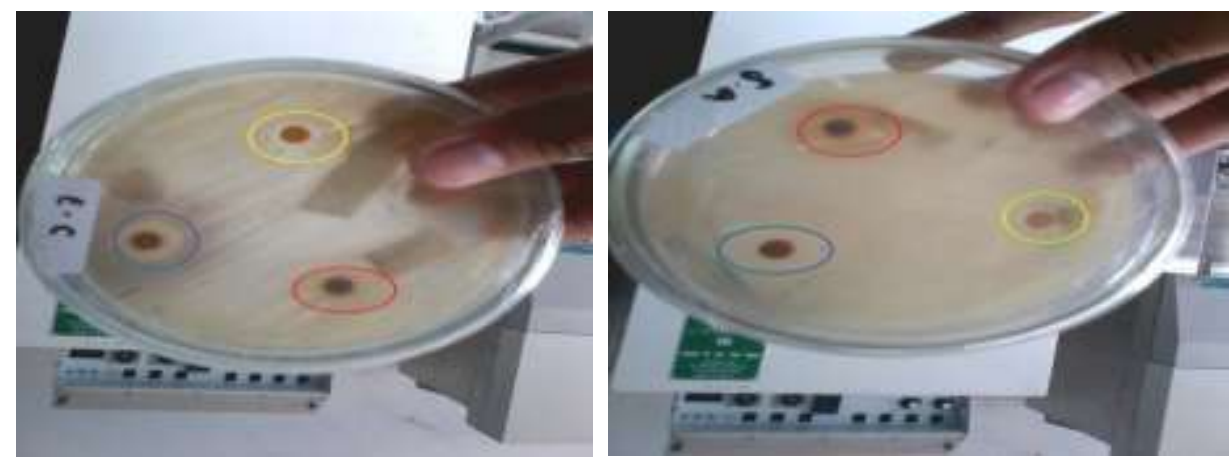

Gambar 1. Uji pendahuluan aktivitas anti bakteri (a).bakteri Escherichia coli, b. Bakteri staphylococus aureus

Keterangan: OEkstrak Aquades $\bigcirc$ Ekstrak Etil asetat $\bigcirc$ EkstrakEtan

Penelitian Gede dkk., (2008) memperoleh senyawa terpenoid aktif terhadap bakteri E.coli. Hal ini sejalan dengan penelitian ini, bahwa ekstrak postif mengandung senyawa terpenoid memiliki daya hambat yang lebih besar di bandingkan ekstrak yang hanya mengandung senyawa steroid. Hal ini di diakibatkan senyawa steroid dalam kodisi terlalu banyak, akan merugikan tubuh, salah satunya adalah menyebabkan diare.

Total fenolik ekstrak buah mengkudu dilakukan untuk mengetahui potensi anti bakteri. Analisis total fenol menggunakan larutan standar asam galat. Kurva standar yang diperoleh memberikan informasi tentang hubungan antara konsentrasi asam galat dengan absorbansinya. Pengunaan asam galat sebagai larutan standar karena asam galat merupakan turunan dari asam hidroksibenzoat yang tergolong asam fenol sederhana dan lebih murah dibandingkan dengan senyawa standar lainnya (Mongkolsilp dkk., 2004). Senyawa fenolik total dapat ditetapkan dengan metode Folin-Ciocalteu. Prinsip dari metode ini adalah reaksi 
reduksi oksidasi. Reagen Folin-Ciocalteu merupakan reagen pengoksidasi berupa larutan berwarna kuning. Senyawa fenolik dalam sampel akan dioksidasi oleh molybdotungstate yang merupakan komponen dari Folin-Ciocalteu membentuk senyawa berwarna biru. Reaksi antara senyawa fenolik dengan Folin-Ciocalteu berjalan lambat pada suasana asam, sehingga perlu penambahan natrium bikarbonat agar terbentuk suasana basa dan reaksi dapat berjalan lebih cepat (Wildan., 2010).

Kerusakan bahan pangan pada umumnya disebabkan oleh aktivitas bakteri. Oleh sebab itu buah mengkudu dapat digunakan sebagai pengawet bahan pangan dengan mengetahui kemampuan senyawa kimia tersebut dalam menghambat bakteri. Penelitian ini diawali dengan uji pendahuluan menggunakan bakteri E.coli dan bakteri S.aureus, untuk melihat aktivitas anti bakteri oleh ekstrak buah mengkudu pada dua jenis bakteri uji. Ekstrak kasar etil asetat dan ekstrak etanol buah mengkudu sama sama dapat menghambat dua jenis bakteri tersebut. Hal ini berarti buah mengkudu dapat menghambat bakteri jenis bakteri gram positif maupun bakteri gram negatif ditandai dengan adanya zona bening.

Kontrol positif dalam penelitian ini menggunakan ampisilin. Kategori sifat bakteri terhadap antibiotik ampisilin adalah resisten apabila zona hambat $\leq 11 \mathrm{~mm}$, intermediet apabila $12-13 \mathrm{~mm}$ dan sensitif apabila $\geq 14 \mathrm{~mm}$ (Pelczar \& Chan, 2005). Hasil ujian aktivitas antibakteri menunjukkan hubungan yang selaras dengan kandungan fenol ekstrak buah mengkudu, semakin tinggi kandungan fenol ekstrak buah mengkudu semakin tinggi pula daya hambat ekstrak tersebut terhadap bakteri E.coli.

Fenolik secara ekstensif sebagai desinfektan yang mempunyai aktivitas antibakteri berspektrum luas terhadap bakteri Gram positif dan Gram negatif. Turunan fenol berinteraksi dengan sel bakteri melalui proses absorbsi yang melibatkan ikatan hidrogen (Tursiman., dkk 2012). Golongan fenol mampu merusak membran sel, menginaktifkan enzim dan mendenaturasi protein sehingga dinding sel mengalami kerusakan karena penurunan permeabilitas. Perubahan permeabilitas membran sitoplasma memungkinkan terganggunya transportasi ion-ion organik yang penting ke dalam sel sehingga berakibat terhambatnya pertumbuhan bahkan hingga kematian sel bakteri (Damayanti dan Suparjana, 2007).

\section{KESIMPULAN}

Ekstrak buah mengkudu memiliki kandungan fenolik total pada ekstrak etanol sebesar 171,91 mg/L dan pada ekstrak etil asetat 23,27 mg/L. Ekstrak etanol dan etil asetat 
buah mengkudu berpotensi dijadikan sebagai zat antibakteri terhadap bakteri Escherichia coli.

\section{DAFTAR PUSTAKA}

Damayanti, E. dan Suparjana. 2007. Efek penghambatan beberapa fraksi ekstrak buah mengkudu terhadap Shigella dysenteriae. Jurnal penelitian sains. 17(3), 136-142.

Gede, B. Gunawan, I. W. G, dan Sutrisnayanti, N. L. 2008. Isolasi Dan Ientifikasi Sesnyawa Terpenoid Yang Aktif Antibakteri Pada Herba Meniran. Jurnal Kimia. 2 (1): 31-39

Harsojo, Andini, L. S., dan Trimey, R. S. 2005. Dekontaminas I Bakteri Patogen pada Daging dan Jeroan Kambing dengan Iridiasi Gamma. Seminar Nasional Teknologi Peternakan dan Veteriner.

Hayati E.K., Fasyah A.G., Sa'adah L., 2010, Fraksinasi dan Identifikasi Senyawa Taninpada Daun Belimbing Wuluh (Averrhoabilimbi L.), Jurnal Kimia, 4(2): 193-200.

Hermawan, G. P. danLaksono.H. 2013. Ekstraksi Daun Sirsak Menggunakan Pelarut Etanol. Jurnal Teknologi Kimia dan Industry, 2, 2,.111-115.

Jayaraman, S. K., dan Muthu, S. M. 2008. Antibakteri, Antifungi dan sel tumor dari eksrtak buah mengkudu. jurnal biology. 3,1 .

Mongkolsilp, S., Pongbupakit, I., Sae-lee, N., Sitthithaworn, W. 2004. Radical Scavenging Activity And Total Phenolic Content Of Medical Plants Used In Primary Health Care. Jurnal of Pharmacy and Science. 9(1) :32-35.

Pelczar, MJ dan Chan, E.C.S. 2005.Dasar Dasar Mikrobiohgi. UI Press. Jakarta. 452-458.

Saraswaty, V., Risdian, C., Budiwati, T. A., danTjandrawati, M. 2013.Aktivitas Antioksidan dari Kombinasi Ekstrak Etanol Kulit Manggis, Daun Sirsak, dan Daun Sirih Merah. Penelitian. Penetitian Disajikan dalam Seminar Nasional 1PT 2013. Pusat Penelitian Kimia LIPI. Yogyakarta: Oktober2013.

Tursiman, Puji Ardiningsih, dan Risa Nofiani. 2012. Total Fenol Fraksi Etil Asetat Dari Buah Asam Kandis (Garcinia Dioica Blume). Prosiding Seminar Nasional Tehnik Kimia. Program Studi Kimia Fakultas Mipa, Universitas Tanjungpura, Kejuangan. Vol 1, Hal $45-48$

Wildan, A.A. 2010.Optimasi Cairan Penyari Pada Pembuatan Ekstrak Daun Pandan Wangi (Pandanus Amaryllifous Roxb) Secara Maserasi Terhadap Kadar Fenolik Dan Flavonoid Total. Momentum, Vol. 6, No. 2, Oktober 2010 : 36 - 41. Sekolah Tinggi Ilmu Farmasi Yayasan Pharmasi Semarang

Winarti,C.2005. Peluang Pengembangan Minuman Fungsional dari Buah Mengkudu (MorindacitrifoliaL.). JurnalLitbang Pertanian. 24, 4149-155.

Yunus., Arisandi, A., Abida, I, W. (2009) Daya Hambat Ekstrak Metanol Rumput Laut (Euchema spinosum) terhadap Bakteri Aeromonas hydrophila. Jurnal Kelautan: 2 (2): 16-22 
Yuarini, D. A. A., Wrasiati, L. P., Hartati, Amna. 2011. Kandungan Senyawa Bioaktif Dan Karakteristik Sensoris Ekstrak Simplisia Bunga Kamboja (Plumeria Sp.). Jurnal Biologi XV (2) : 39-43. 